Policy Research Working Paper 2564

Economic Analysis of World ourcoms on wort Bank Bank Education Projects and education projects are better when the quality of project Project Outcomes appraisal is good.

Ayesha Yaqub Vawda

Peter Moock

J. Price Gittinger

Harry Anthony Patrinos

The World Bank

Human Development Network

Education Team

and

East Asia and Pacific Region

Human Development Sector Unit

March 2001 
Policy Research Working Paper 2564

\section{Summary findings}

Research reported in this paper tests the hypothesis that Bank education projects for which the project appraisal documents are judged "good" have a higher probability of leading to successful outcomes than projects for which the appraisals are judged "poor."

The research draws on project document evaluations carried out between 1993 and 1998 .

Analysis shows a strong relationship between the quality of cost-benefit and cost-effectiveness analysis and the quality of project outcomes. Economic analysis of projects is a tool for weeding out potentially poor

investments and selecting potentially worthwhile ones. The economic analysis can be used to select among alternative projects or to redesign project components so that they yield more and produce better outcomes.

Good practice education projects require good economic analysis-analysis of demand, of the counterfactual private sector supply, of the project's fiscal impact, of lending's fungibility - and strong sector work before project design.

This paper-a joint product of the Education Team, Human Development Network, and the Human Development Sector Unit, East Asia and Pacific Region-is part of a larger effort in the Bank to improve the quality of education projects. The study was funded by the Bank's Research Support Budget under the research project "Economic Analysis in Education Projects" (RPO 682-95). Copies of this paper are available free from the World Bank, $1818 \mathrm{H}$ Street NW, Washington, DC 20433. Please contact Energy James, room G8-058, telephone 202-473-1756, fax 202-522-3233, email address ejames2@worldbank.org. Policy Research Working Papers are also posted on the Web at http://econ.worldbank.org. The authors may be contacted at avawda@worldbank.org, pmoock@worldbank.org, or hpatrinos@worldbank.org. March 2001. (34 pages)

The Policy Research Working Paper Series disseminates the findings of work in progress to encourage the exchange of ideas about development issues. An objective of the series is to get the findings out quickly, even if the presentations are less than fully polished. The papers carry the names of the authors and should be cited accordingly. The findings, interpretations, and conclusions expressed in this paper are entirely those of the authors. They do not necessarily represent the view of the World Bank, its Executive Directors, or the countries they represent. 


\section{Economic Analysis of World Bank Education Projects and Project Outcomes ${ }^{1}$}

Ayesha Vawda, Peter Moock, J. Price Gittinger and Harry Patrinos

\footnotetext{
${ }^{1}$ Research supported by the Research Advisory Group, World Bank, under the project "Economic Analysis in Education Projects" (RSP 682-95) and the Economics of Education Thematic Group (http://www.worldbank.org/education/economicsed). Comments received from George Psacharopoulos and Emmanuel Jimenez are gratefully acknowledged.
} 



\title{
Economic Analysis of Education Projects and Project Outcomes
}

\author{
Ayesha Vawda, Peter Moock, J. Price Gittinger, and Harry Patrinos
}

The research reported in this paper tests the hypothesis that World Bank staff appraisal reports (SARs) or project appraisal documents (PADs) $)^{2}$ of education projects which are judged "good" have a higher probability of leading to successful project outcomes than projects for which the SARs or PADs are judged "poor." The research draws upon the series of project document evaluations carried out between 1993 and 1998, which are generally collectively referred to as the "ECON" reports ${ }^{3}$ and upon project supervision evaluations. ${ }^{4}$

\section{Sources and Evolution of World Bank Approach to Education Investment}

World Bank thinking about the economic analysis of education projects traces back to the seminal work of Theodore W. Schultz who first re-discovered the concept of human capital theory in his presidential address to the American Economic Association in December $19600^{5} \mathrm{He}$ subsequently expanded his concepts in a special issue of Journal of Political Economy in $1962 .^{6}$ This same issue of the $J P E$ also contained an article by Gary Becker which pre-viewed the

\footnotetext{
${ }^{2}$ Project Appraisal Documents or PADs (formerly called Staff Appraisal Reports or SARs) are documents drawn up by project teams and finalized during the appraisal process of a proposed World Bank project. They contain detailed project description (including objectives, components), monetary allocations, proposed implementation plan and costing as well as description of the analyses used to justify the proposed project.

${ }^{3}$ Economic Analysis of Projects: Towards a Results-oriented Approach to Evaluation. Memorandum. Washington, D. C.: World Bank, 1993; A Review of the Quality of Economic Analysis in Staff Appraisal Reports for Projects Approved in 1993. Memorandum. Washington, D.C.: World Bank, 1995. An Interim Review of the Quality of Economic Analysis in Staff Appraisal Reports for Projects Approved in Fiscal Year 1996. Memorandum. Washington, D.C.: World Bank, 1996; A Review of the Quality of Economic Analysis in SARs for Projects Approved in Fiscal Year 1996. Memorandum. Washington, D.C.: World Bank, 1997; Economic Analysis of Investment Projects. Education Sector. Fiscal Year 1997. Memorandum. Washington, D.C.: World Bank 1998; Review of the Quality of Economic Analysis in Fiscal Year 98 Education Project Appraisal Documents and Staff Appraisal Reports. Memorandum. Washington, D.C.: World Bank, 1998.

${ }^{4}$ Reported in the Project Status Report (PSR, formerly titled form 590), a report submitted upon completion of project supervision, indicating the progress of project implementation and highlighting possible problems.

${ }^{5}$ Theodore W. Schultz. "Investment in Education." American Economic Review 51:1-17, 1961.
} 
preliminary chapters of his ground-breaking 1964 book that has been a foundation of thinking about human capital ever since. Economists were quick to take up the new theory and a large number of publications appeared as journal articles and books, including Schultz' The Economic Value of Education. ${ }^{8}$

Despite the ferment of human capital thinking in academic circles in the late 1950 s and early 1960s, as Phillip Jones asserts, "there is no evidence that senior Bank management embraced education because of new ideas about the development of human capital or human resources."9 Jones details how thinking within the World Bank grew, instead, out of World Bank project lending experience and the pragmatic realization that developing countries lacked the trained manpower to administer a large development program. Eugene Black, during his tenure as president of the World Bank from 1949 to 1962, actively supported lending for education, but few other senior World Bank managers were supportive in those years. Gradually, however, the idea took hold that the World Bank needed to have an education lending policy and portfolio. A series of internal discussions and memoranda explored options for support to education and many of the leading academic specialists were consulted. Slowly an approach emerged. The World Bank would not build a large education staff. Rather it would rely on UNESCO (the United Nations Education, Scientific and Cultural Organisation) based in Paris to carry out sector studies and project feasibility studies. ${ }^{10}$ By October 1963 George Woods, Black's successor as president, sent to the Board a paper on Proposed Bank/IDA Policies in the Field of Education. This stated:

In most developing countries ... the most urgent need is for (a) an expansion of vocational and technical education and training at various levels, including

\footnotetext{
${ }^{6}$ Theodore W. Schultz. "Investment in Human Beings." Journal of Political Economy, October 1962. ${ }^{7}$ Gary S. Becker. Human Capital. 2nd ed. New York: Columbia University Press, 1975. [The first edition was published in 1964.]

${ }^{8}$ Theodore W. Schultz. The Economic Value of Education. New York: Columbia University Press, 1963.

${ }^{9}$ Phillip W. Jones. World Bank Financing of Education. London and New York: Routledge, 1992. p. 37.

${ }^{10}$ Jones, op. cit. pp. 32-58.
} 
technical schools, agricultural schools and schools of commerce and business administration; and (b) an expansion of general secondary education, to provide middle-level management for government, industry, commerce and agriculture, more candidates for higher education and for specialized vocational training, and more teachers for the primary schools. ${ }^{11}$

Thus the policy was established. The World Bank would concentrate primarily on highly vocational educational activities with a heavy emphasis on "bricks and mortar," that is, on building construction. Indeed, the majority of the World Bank's education staff in the first years of lending for education were architects.

World Bank lending for education began rather slowly, although a number of countries had expressed interest in borrowing for this purpose in the late 1950s and early 1960s. The first loan in 1962 was to Tunisia for construction of secondary schools. (This loan was made before the George Woods' formalized statement of World Bank lending principles for education, cited above, was finalized in 1963.) However, by fiscal year 1968 the World Bank had made loans for 25 projects in 23 countries. Almost four-fifths of this lending was on concessional terms in the form of International Development Association (IDA) credits. These education projects, for the most part, involved construction of secondary schools, technical schools and teacher education colleges. The project documentation contained very little in the way of economic analysis.

Indeed, in an attempt to encourage World Bank education specialists and economists to undertake more formal economic analysis of education projects, the then Director of the Economics Department, Andrew M. Kamarck, commissioned a monograph in 1967 by the

\footnotetext{
${ }^{11}$ World Bank. Proposed Bank/IDA Policies $n$ the Field of Education. Washington, D.C.: World Bank,
} 1963. 
education economist Mark Blaug of the University of London Institute of Education and the London School of Economics. ${ }^{12}$ In his preface to the monograph Kamarck noted:

This study originated from a growing awareness that the methods currently used in planning expenditure for education in developing countries fail to take into account important links between the educational system and the economy. For one thing, current methods take the economic value of more education largely for granted; they do not attempt to measure the benefits of the various types of education in monetary terms, thus precluding systematic economic analysis of the benefits as well as the costs of providing additional education by type and level. As a corollary, little, if any, attention is being paid to the role of earnings in the demand for and supply of educated people in a country ... ${ }^{13}$

Blaug recommended that the World Bank use cost-benefit analysis for education project evaluation (rather than manpower forecasts): “. . the scarce resources available for education in each country should be husbanded according to a scale of priorities which reflect, however crudely, the estimated costs and expected benefits of educational projects. By benefits we mean the productivity of educated people ...,14

Jones notes much the same lack of attention to economic analysis as did Kamarck. He comments that as of 1968 :

It is interesting that issues to do with economic aspects of lending to education took a back seat, and were not at all systematically explored by Bank education staff. This is in stark contrast to the intensive inquiry into the economics of

\footnotetext{
12 -1ark Blaug. A Cost-Benefit Approach to Educational Planning in Developing Countries. Report No. EC-157. Washington, D.C.: World Bank, 1967.

${ }^{13}$ Andrew M. Kamarck "Preface." In Blaug, op. cit. p. ii.

${ }^{14}$ Blaug, op. cit., p. 40.
} 
education and human capital theory that senior economic and $T$ [echnical] O[perations] $\mathrm{D}$ [epartment] staff had initiated in the period 1960-63. By contrast, the newly-appointed education staff had projects as their central concern and did very little from the start to explore systematically the economic dynamics of education systems and reforms. In fact such a concern was not to become a priority for another decade. It was a wasted opportunity. ${ }^{15}$

The inattention to more formal analysis of costs and benefits in education projects should not be attributed to a general lack of knowledge about cost-benefit analysis. Education economists outside the World Bank, in academic institutions mostly, had been doing cost-benefit analyses since the late 1950 s. $^{16}$ In the same time period, World Bank staff were using discounted cash flow analysis to analyze electricity projects, and the first cost-benefit analysis of an agricultural project was done in $1961 .{ }^{17}$ By the late 1960 s the World Bank was a leader in using discounted cash flow analysis for cost-benefit analyses with a fully developed methodology for shadow pricing foreign exchange and project outputs and inputs including labor.

Such sophisticated methodologies did not very often find their way into the World Bank's education sector, however, with some exceptions. Internal rates of return were computed for vocational education projects in Chile in fiscal year 1966 and Thailand in fiscal year $1967 .^{18}$ The World Bank also commissioned a study intended to demonstrate the relevance of cost-benefit analysis for educational planning and for World Bank education project identification and preparation done by or on behalf of World Bank staff..$^{19}$ However, the use of cost-benefit analysis

\footnotetext{
${ }^{15}$ Jones. op. cit. p. 83 .

${ }^{16} \mathrm{H}$. W. Arndt. Economic Development: The History of an Idea. Chicago: University of Chicago Press, 1987.

${ }^{17}$ Edward S. Mason and Robert F. Asher. The World Bank Since Bretton Woods. Washington, D.C.: The Brookings Institution, 1973. p. 241.

${ }^{18}$ Robert Picciotto. Memorandum. November 3, 1994.

${ }^{19}$ Hans Heinrich Thias and Martin Carnoy. Cost-Benefit Analysis in Education: A Case Study of Kenya. Baltimore: Johns Hopkins University Press, 1972.
} 
to justify World Bank education projects was not widespread and even in the 1990s the World Bank Operational Policy guideline OP10.04 $4^{20}$ exempted education projects from the general requirement that cost-benefit analyses be conducted as part of project preparation and be included in every staff appraisal report. As a result, few were done for education projects, this despite the fact that sectoral rates of return on investments in education were as high as 20 percent in the period 1974-92. ${ }^{21}$ In fact, in the first of the series of ECON reports ("ECON-I,22) which analyzed World Bank projects approved in fiscal year 1991 cost-benefit analyses were not evaluated in the case of education projects. The reason given was the exemption contained in OP 10.04 (education projects were, however, judged on other aspects of economic analysis in ECON-I).

The rationale for exempting education projects had to do with the supposed difficulty of measuring the economic benefits of education - not all of which are monetary but may be "psychic" only; some of which are captured by society at large and not by the educated person (so-called "externalities"); and most of which continue to accrue for many years after the investment is in place. The likelihood of "psychic returns" and "externalities," however, and the fact of a long "gestation period" are characteristics not unique to investments in education. The problems anticipated '.l doing project economic analysis for education are, in fact, much the same as those encountered by economists working in other sectors, transport and power, for example. The "special treatment" afforded education projects under OP10.04 led to the absence of any outcome specification, thus making it extremely difficult to judge project outcomes. It was also extremely rare to find any unit costs or quantitative analysis of alternatives. Such "special treatment" to education also contributed, ironically, to a misperception on the part of some World Bank economists that education is a "soft sector," and it reinforced the reluctance on the part of

\footnotetext{
${ }^{20}$ Operational guidelines are procedures and operational policies defining lending and supervision activities of the World Bank for World Bank credits.

${ }^{21}$ George Psacharopoulos. "Returns to Investment in Education: a Global Update." World Development 22(9) 1325-1343, 1994.

${ }^{22}$ Economic Analysis of Projects: Towards a Results-oriented Approach to Evaluation. loc. cit.
} 
some finance ministries to borrow for education, or to borrow only on soft terms and to stop borrowing when the country had "graduated" from IDA to IBRD borrowing status.

In 1994, Graham Donaldson of the Operations Evaluation Department responded to an inquiry from a Board ${ }^{23}$ member by outlining the World Bank approach to cost-benefit analysis in education projects: ${ }^{24}$

It is standard practice that Education projects are not subject to cost-benefit, nor to cost effectiveness analysis prior to project approval. This dates from decisions taken in the early 1970 s and never reassessed. As far as I can tell, no education projects have been subject to formal ex ante cost-benefit analysis in the past two decades ...

Having reviewed Agriculture sector and Education sector projects for the better part of 10 years I am struck by the fact that agriculture is subject to costbenefit analysis and education is not. I can see no reason for this anomaly - the assumptions to be made in estimating an ERR for education are no more challenging (or heroic) than those for agriculture. There is an established literature going back to the 1950 's dealing with the application of cost-benefit to education projects. $^{25}$

The consequence of not applying cost-benefit to education projects can be seen in the poor definition of project objectives and poorly developed sequencing of expenditure related activities and the lack of any time related consideration of

\footnotetext{
${ }^{23}$ Define Board

${ }^{24}$ Graham Donaldson, memorandum, November 3, 1994.

${ }^{25}$ In this sentence, Donaldson probably misspoke in some technical sense. Nearly all of the established literature dealing with cost-benefit analysis in education at this time was cost-benefit of sector investments in education. With the Bank (as the largest source of external financing for education projects undertaken in the developing world) having failed in its responsibility to carry out cost-benefit analyses of education projects, most other funding agencies simply followed suit, and few such analyses were, in fact, done before the mid-1990s.
} 
the benefits from project components. The lack of attention to detailing project objectives is of particular concern - this has far reaching implications for the success of projects and the way in which we assess them. Evaluation depends on assessing the character of objectives (challenging, risky, simple, complex), whether they have endured or been changed (and why) and the extent to which they have been realized.

Although there was little use of cost-benefit analysis in World Bank education projects until well into the $1990 \mathrm{~s}$, there was, beginning in the early $1980 \mathrm{~s}$, a notable development in the use of cost-benefit analysis to assess the value of sectoral investment in education - that is, investment in the sector as a whole as opposed to investment in a particular project. This was the research conducted and/or synthesized and reviewed by George Psacharopoulos and others. Psacharopoulos had written on returns to education before coming to the World Bank in $1980^{26}$ but after coming to the World Bank he published a series of studies on the returns to sectoral investment in education, beginning with Higher Education in Developing Countries: $A$ CostBenefit Analysis. ${ }^{27}$ His work clearly showed the substantial returns to be realized from education sector investment at all levels - primary, secondary and tertiary. Interestingly, the highest rates of return were found at the primary level, partly because primary education is relatively cheap to provide and partly because the opportunity cost of young children attending school is also low. While at the World Bank, Psacharopoulos continued to chronicle the empirical results of many researchers around the world who were busy estimating private and public returns to education. ${ }^{28}$ A project is currently being undertaken by the Economics of Education Thematic Group which compiles rates of return data from 1960s to the present.

\footnotetext{
${ }^{26}$ George Psacharopoulos. Returns to Education: An International Comparison. Amsterdam: Elsevier Scientific Publishing Company, 1973.

${ }^{27}$ George Psacharopoulos. Higher Education in Developing Countries: A Cost-Benefit Analysis. Staff Working Paper 440. Washington, D.C.: World Bank, 1980.

${ }^{28}$ George Psacharopoulos. "Returns to Investment in Education: a Global Update." loc. cit.
} 
Psacharopoulos' work (and that of others in the field) became increasingly well known within the World Bank. Ironically, some World Bank education staff believed there was no need to conduct cost-benefit analyses of the projects they were preparing for the very reason that research had demonstrated so convincingly the high sectoral returns to education investment.

Another reason for the lack of enthusiasm for doing cost-benefit analysis of individual education projects was the firm belief on the part of most education specialists that there are large externalities associated with education and that these are difficult, if not impossible, to quantify. While difficult, some empirical work (and even more theoretical work) on externalities was being done. While Psacharopoulos and most other education economists were focusing on earnings differentials as the sole measure of returns in education, a few researchers were beginning to think more about externalities associated with education. Haveman and Wolfe, for example, identified 19 benefits in addition to income differentials based on level of education, ${ }^{29}$ and within the World Bank, Patrinos argued:

Widespread public education at the basic level may provide a threshold for development ... Governments should: redefine what the state and the individual will finance, shifting the pattern of public subsidization and public provision to bring private returns more fully in line with social returns, to deal with information asymmetries between households and government; to achieve equity; to correct market failures; and to fund investment in pure public goods and where social returns are high but private returns are too low to stimulate investment. ${ }^{30}$

\footnotetext{
${ }^{29}$ Robert Haveman and Barbara Wolfe. "Schooling and Economic Well-Being: the Role of Non-market Effects." Journal of Human Resources 19(3):377-407, 1984.

${ }^{30}$ H. A. Patrinos. Financing Education. Memorandum. April 1994.
} 
Simply assuming that there may be externalities associated with education, however, is not sufficient to justify any particular education investment. Mingat and Tan found that the level of economic development greatly influences the rates of return from expanding educational coverage. "Our results suggest that low-income countries benefited most from investments to expand primary education, while in middle-income countries, it was investments to expand secondary education that brought the highest social returns. In the high-income countries, investing to expand coverage in higher education yielded the best returns., ${ }^{\text {, } 1}$

By the early 1990s, the prevailing views of World Bank education specialists had begun to change. Economic analysis, broadly defined, began to appear more prominently in staff appraisal reports of education projects, and (particularly germane to the question addressed in this research study) analysis was used more and more commonly to justify particular education investments and policy interventions. Among the fiscal year 1991 education SARs evaluated as part of ECON-I, none includer a cost-benefit analysis. ${ }^{32}$ By way of contrast, in the most recent review of projects approved in fiscal year 1998, 41 percent (15 of 37) did so. ${ }^{33}$

ECON-I and is successors ${ }^{34}$ suggest that the quality of economic analysis in education has improved during this decade. The proportion of education project analyses rated as "good" or "acceptable" has risen from 73 percent of those reviewed in calendar year 1993 to 94 percent in fiscal year 1998 (Annex 5 provides some good practice examples). One can extrapolate from this finding and conclude that fewer projects of dubious economic value "slip through the net" today than in the past, and that those projects which get past the appraisal stage and go to the Board for

\footnotetext{
${ }^{31}$ Alan Mingat and Jee-Peng Tan. The Full Social Returns to Education: Estimates Based on Countries' Economic Growth Performance. Human Capital Development Working Paper 73. Washington, D. C.: World Bank, 1996.

${ }^{32}$ Economic Analysis of Projects: Towards a Results-oriented Approach to Evaluation. Memorandum. Washington, D. C.: World Bank, 1993.

${ }^{33}$ Review of the Quality of Economic Analysis in FISCAL YEAR 98 Education Project Appraisal Documents and Staff Appraisal Reports. Washington, D.C.: Economics of Education Thematic Group, World Bank, 1998. p. 1.

${ }^{34}$ See footnote 2 .
} 
approval are, in general, higher-value projects - either because they were good to begin with, or because the economic analysis led to their redesign or the elimination of marginal (low-value) project components during the period of project preparation.

\section{Purpose of Project Economic Analysis}

High sectoral returns to education investment do not indicate that any particular education project will yield high returns relative to the costs of the project and relative to the returns on alternative projects. Thus, a project analysis should include an economic analysis which looks at the costs and benefits associated with the particular project investment, notoverall investment in the sector as a whole. To decide whether a particular education project is something on which society should spend its scarce investment resources, a project economic analysis should include a rate of return estimate. If the project creates skills that lead to higher earnings, then the additional earnings of those benefiting under the project can be used as an estimate of project returns. If the project results in significant internal efficiency gains (such as when drop-outs and repetition are reduced in response to a more appropriate curriculum or increased availability of teaching/learning materials), then the cost savings may be a good measure of project benefits. If the project results in increased cost recovery, and shifts expenditure from the public to the private sector, thus freeing public funds for other high priority social investments for which private funds are not forthcoming, then this, too, can be counted as a return to the resources invested under the project.

The purpose of project economic analysis is to distinguish among potential projects and select that project which promises to contribute the most to the economic welfare of the country. The scarcity of funding makes it necessary for national decision-makers to be selective. This is especially true for poor developing countries. Even many good projects have to be passed up in the absence of resources for project funding. Only the best project should be selected, therefore, 
and when that project is underway, if additional financing is available then the next best project and so on.

It may be true as well that a project for which the economic analysis is good or excellent will be easier to implement and will tend to be given a higher rating on the expected achievement of development objectives during project supervision and after project completion.

The study reported here is based on a sample of 104 education projects which became effective between 1994 and 1998. All of the 104 projects have been evaluated in terms of the quality of their economic analysis. Given that there is variation in the number of years since project effectiveness, this study can address in part whether the relationship between the quality of economic analysis and project "outcomes" (for example, implementation progress or achievement of development objectives) holds at all stages of project implementation.

But even if the relationship is found to hold throughout the life of the project, there remains another question about causality. A correlation between project economic analysis (variable A) and project outcomes during project implementation or after project completion (variable B) could mean that A causes B, or it could mean that other factors which cause A also cause B. For example, a technically competent and highly dedicated project preparation team is likely to carry out good economic analysis (and, therefore, to select and design project components that will make valuable contributions to the economic welfare of the country), but the same team is likely to do most other things well too. These other things, and not the economic analysis per se, may explain the successful implementation and higher development impact of the project.

In other words, good economic analysis, while it may be a good predictor of project success, may not cause project success directly. Thus, it is possible to find a project which was successfully implemented but which contributed little to the economic welfare of the country, 
perhaps because no economic analysis was conducted, or because the analysis that was conducted was bad. Inadequate economic analysis resulted in the project being selected, when it should have been rejected. By the same token, it is possible to find a project that might have contributed a lot to economic welfare, if only it had been implemented successfully — but this did not happen for reasons that had nothing to do with the quality of the economic analysis.

The two hypothetical cases just given are likely to be statistical "outliers." In more cases than not, good economic analysis probably does go hand-in-hand with successful project outcomes. The objective of this study is to test this hypothesis.

\section{Statistical Analysis}

This study is based on a sample of 104 education projects approved between 1993 and 1998. ${ }^{35}$ ECON ratings for each of the ten dimensions of economic analysis (see Annex 1) are used as proxies for the quality of the economic analysis at the project design stage. The most recent expected development objective (DO) ratings and project implementation progress (IP) ratings are used as indicators of project outcome. ${ }^{36}$ Control variables include region of the World Bank and project age-variables which are likely to affect project outcomes and which could be related also to quality of project economic analysis. Effectiveness lag was used in early stages of this research as a control variable but later dropped because effectiveness lag is an intervening variable, i.e., poor economic analysis may increase the lag, which in turn affects project

\footnotetext{
${ }^{35}$ This includes all education projects approved in CY 1993 and FYs 1996-1998. The sample was limited to those projects for which ECON ratings have been done.

${ }^{36}$ The rating of an operation's Development Objective (DO) is based on the likelihood of attaining the development objectives set in the PAD (or formally revised during implementation). This rating may be satisfactory or unsatisfactory and is responsibility of the task manager, who reports it generally every six months in the Project Status Report (PSR) (formerly the form 590). The DO rating takes into account not only implementation progress, but also other facts, such as inappropriate design, unforeseeable adverse economic and financial development, price fluctuations of project outputs, and changes in government policy. The Implementation Progress (IP) rating is based on an overall judgement of implementation performance in relation to the benchmarks in the PAD or as formally revised during implementation. The rating is the responsibility of the task team leader, who reports it generally every six months in the PSR.
} 
outcomes. Very few projects in the sample have reached completion. Thus, the analysis does not incorporate post-completion evaluation of project effectiveness.

Data

The sample of 104 projects represents education projects in all regions of the World Bank's operations. The highest number of projects in the sample (30) are in the LAC Region, followed by AFR (22), EAP (20), SAR (14), ECA (10) and MNA (8).

Bank-wide in the education sector, the dimension of economic analysis receiving the lowest ECON ratings is the "analysis of alternatives" (42 percent, see Table 1). The proportion of projects receiving less than satisfactory ratings on this dimension ranged from 29 percent in SAR to 55 percent in EAP. One out of three education projects had less than acceptable ratings for the "quality and clarity of cost benefit/cost-effectiveness (CB/CE) analysis." While all regions fare poorly in this category, MNA does the best (17 percent less than satisfactory) and SAR the worst (60 percent less than satisfactory). One out of four education projects had marginal or poor ratings for the quality of "beneficiary assessment and poverty analysis," with MNA doing worse (50 percent less than satisfactory) than any other region, followed by EAP ( 40 percent less than satisfactory) and ECA (30 percent less than satisfactory). 
Table 1: Regional Distribution of Projects Rated "Marginal" or "Poor" on Different Dimensions of Economic Analysis, 1993-98

\begin{tabular}{lccccccc}
\hline & \multicolumn{7}{c}{ Region } \\
\cline { 2 - 7 } Dimensions of Economic Analysis $^{\text {a }}$ & AFR & EAP & ECA & LAC & MNA & SAR & All \\
\hline 1. ESW and CAS & $5 \%$ & $10 \%$ & $20 \%$ & $10 \%$ & $13 \%$ & $0 \%$ & $9 \%$ \\
2. Analysis of Alternatives & $36 \%$ & $55 \%$ & $40 \%$ & $47 \%$ & $38 \%$ & $29 \%$ & $42 \%$ \\
3. Fiscal Impact Analysis/Cost recovery & $9 \%$ & $20 \%$ & $30 \%$ & $13 \%$ & $13 \%$ & $14 \%$ & $15 \%$ \\
4. Quality and Clarity of CB/CE analysis ${ }^{b}$ & $25 \%$ & $29 \%$ & $40 \%$ & $35 \%$ & $17 \%$ & $60 \%$ & $34 \%$ \\
6. Institutional Risk Analysis & $5 \%$ & $25 \%$ & $40 \%$ & $17 \%$ & $13 \%$ & $7 \%$ & $16 \%$ \\
7. Beneficiary Assessment \& Poverty & $27 \%$ & $40 \%$ & $30 \%$ & $17 \%$ & $50 \%$ & $7 \%$ & $26 \%$ \\
$\quad$ Analysis $^{c}$ & & & & & & & \\
10. Overall Rating & $9 \%$ & $25 \%$ & $20 \%$ & $20 \%$ & $25 \%$ & $7 \%$ & $17 \%$ \\
N (number of projects in regional sample) & 22 & 20 & 10 & 30 & 8 & 14 & 104 \\
\hline
\end{tabular}

Sources: ECON Reports 1993, 1996, 1997, 1998, 1999

${ }^{a}$ No ECON ratings for three of the ten dimensions of economic analysis:

5. Sensitivity Analysis

8. Environmental Analysis

9. Economic Performance Criteria

${ }^{\mathrm{b}}$ Number of projects in regional samples for Dimension 4: AFR (16); EAP (14); ECA (10); LAC (23); MNA (6); SAR (10).

${ }^{c}$ Number of projects in LAC regional sample for Dimension 7: 29.

On the positive side, however, as earlier pointed out, an upward trend was noted in all regions and for all dimensions for education projects in the more recent ECON reports. As indicated in Table 2, 92 percent of education projects approved in FY98 were rated either "good" or "acceptable" for the overall quality of economic analysis, as compared with 74 percent of CY93 projects.

Table 2: ECON Ratings of the Quality of Education Project Economic Analysis, 1993-98 (Percent)

\begin{tabular}{lcc}
\hline & \multicolumn{2}{c}{ ECON Ratings } \\
\cline { 2 - 3 } & \multicolumn{3}{c}{ "Good" or "Acceptable" } & "Marginal" or "Poor" \\
\cline { 2 - 3 } CY 93 Projects & 74 & 26 \\
FY 96 Projects & 69 & 31 \\
FY 97 Projects & 94 & 6 \\
FY 98 Projects & 92 & 8 \\
\hline
\end{tabular}

Sources: ECON Reports 1993, 1996, 1997, 1998, 1999. 
Results of the most recent (June 30, 1999) project implementation ratings indicate that approximately one out of every ten education projects is rated as less than satisfactory on the expected achievement of development objectives (DO)- see Table 3. The proportion of projects exhibiting less than satisfactory implementation progress (IP) is nearly twice as high (19 percent).

Table 3: Regional Distribution of Projects Rated "Unsatisfactory" or "Highly Unsatisfactory" on Two Dimensions of Project Outcomes

June, 1999

\begin{tabular}{lccccccc}
\hline & \multicolumn{7}{c}{ Region } \\
& AFR & EAP & ECA & LAC & MNA & SAR & All \\
\hline Development Objectives & $27 \%$ & $0 \%$ & $10 \%$ & $0 \%$ & $0 \%$ & $29 \%$ & $11 \%$ \\
Implementation Progress & $32 \%$ & $5 \%$ & $30 \%$ & $13 \%$ & $0 \%$ & $63 \%$ & $19 \%$ \\
Number of projects in regional sample & 22 & 20 & 10 & 30 & $\mathbf{8}$ & 14 & 104 \\
\hline
\end{tabular}

Source: Project Supervision Reports, June, 1999.

Breakdowns of project analysis and outcome

Breakdowns of project economic analysis and project outcomes by (1) region of the World Bank and (2) project age were undertaken as a first cut at determining the relationship between the quality of project economic analysis and project outcomes (see Annex 2).

The breakdowns indicate no clear relationship between DO ratings and the quality of overall economic analysis (dimension 10--see Annex 1) at the project design stage. In all regions and cohorts, the proportion of "unsatisfactory" DO ratings is about the same regardless of the rating on overall project economic analysis. Interestingly, the proportion of projects with "satisfactory" or better DO ratings is almost three times higher for projects accorded "good" ratings for the quality of cost-benefit/cost-effectiveness analysis (CB/CE) (dimension 4 , see Annex 1) at the design stage than for projects rated less than "good" on the quality of $\mathrm{CB} / \mathrm{CE}$ analysis. While the observed relationship between $\mathrm{CB} / \mathrm{CE}$ and $\mathrm{DO}$ seems stronger than the relationship between overall economic analysis and $\mathrm{DO}$, this relationship appears to be weaker than that between IP and both these indicators of the quality of project analysis (see Annex 2). 
The quality of project economic analysis was found to be linked to the project IP rating and not to the project DO rating. This result seems counter-intuitive if one assumes that within the same project status report, DO and IP would be highly correlated. However, the Pearson's correlation coefficient between DO and IP ratings is .588 (statistically significant at the 99 percent level), indicating a moderate relation between the two variables.

Evidence to support a relation between DO rating and project economic analysis is lacking, possibly because expected achievement of project development objectives is an inadequate indicator of project outcomes. Project teams may be optimistic about the projects' outcomes despite problems during implementation, thus resulting in a disconnect between expected and actual DO achievement. A current OED study reviews the net disconnect between DO ratings and OED outcome ratings upon project close.

\section{Cross-tabulations}

Results of Pearson's Chi-square tests indicate that not all dimensions of project economic analysis are positively related with expected DO ratings (see Annex 4). Expected DO ratings are found to be negatively related with all but two of the dimensions of economic analysis-quality of $\mathrm{CB} / \mathrm{CE}$ analysis and beneficiary assessment and poverty analysis. Lack of adequate information limits thorough explanations for this apparent mismatch. One possible reason for this may be, as noted earlier, a possible disconnect between DO ratings during project implementation and upon project close.

The directions of the cross-tabulations between IP and dimensions of project economic analysis affirm the research hypothesis. Four of the estimated coefficients are statistically significant-quality of $\mathrm{CB} / \mathrm{CE}$ analysis being significant at the 5 percent margin of error. This result encouraged further statistical analysis-multivariate regression analysis- to study the relationship between the quality of economic analysis and project outcome. 
Expected achievement of DO seems intuitively to be a better indicator of project outcomes. However, in the multivariate regression analysis, IP rating is used as a proxy indicator for project outcomes. This is based on the results of the breakdown and the predicted statistically significant relationship between IP and project analysis-especially quality of $\mathrm{CB} / \mathrm{CE}$ analysis.

Multivariate Logistic Regression Analysis

In 1995, two World Bank economists carried out an analysis that showed that projects rated as good or excellent in terms of the economic analysis conducted during preparation were more likely to be given high ratings in terms of their expected achievement of development objectives three years later. ${ }^{37}$ More precisely, the authors found that "the probability that a project will be rated poorly three years after becoming effective is seven time higher if the economic analysis in the Staff Appraisal Report was bad than if the economic analysis was good." The authors concluded that good economic analysis "leads to better projects," while adding the caveat that this relationship had been measured only three years into project implementation and, conceivably, might not hold throughout the life of the project (see Table 4).

Table 4: Probability of Obtaining an Unsatisfactory or Highly Unsatisfactory Rating as a Function of the Quality of the Economic Analysis (percent)

\begin{tabular}{cccccc}
\hline Economic Analysis Rating & \multicolumn{5}{c}{ Development Objective Rating } \\
\cline { 2 - 6 } & EAP & LAC & SAS & AFR & Bank \\
\hline 1 & 1.3 & 7.1 & 5.5 & 5.9 & 4.6 \\
2 & 3.0 & 15.2 & 12.0 & 12.8 & 9.4 \\
3 & 6.7 & 29.6 & 24.1 & 25.6 & 18.3 \\
4 & 14.7 & 49.6 & 42.7 & 44.6 & 32.7 \\
\hline
\end{tabular}

Source: P. Belli and L. Pritchett, "Does Good Economic Analysis Lead to Better Projects?" HCO Dissemination Notes No. 53. Washington, D.C.: World Bank, 1995.

In this study, multivariate logit models are estimated to test the results of the 1995 study for education projects and to gain further insight into the relationship between project economic 
analysis and outcome. Given the results of the bivariate estimations, IP rating was used as a proxy for project outcomes and rating on the quality of $\mathrm{CB} / \mathrm{CE}$ analysis was used as a proxy for the quality of project economic analysis at project design stage. Regional dummies and project age were used as controls in this model.

The regression results of this study reaffirm the results of the Belli and Pritchett study and indicate that, controlling for project region, the quality of economic analysis is a statistically significant predictor of project outcome (see Annex 4, Logit 1). Predicted probabilities of obtaining less than satisfactory IP ratings are derived from the estimated regression coefficients and indicated in Table 5.

Table 5: Probability of Obtaining an "Unsatisfactory" or "Highly Unsatisfactory" Rating as a Function of the Quality of the Project Economic Analysis

(percent)

\begin{tabular}{lcccccc}
\hline Economic Analysis Rating & AFR & EAP & SAR & ECA & LAC & Bank \\
\hline 1 "Good" & $17 \%$ & $4 \%$ & $14 \%$ & $18 \%$ & $9 \%$ & $4 \%$ \\
2 "Acceptable" & $26 \%$ & $6 \%$ & $23 \%$ & $27 \%$ & $15 \%$ & $7 \%$ \\
3 "Marginal" & $38 \%$ & $11 \%$ & $34 \%$ & $38 \%$ & $23 \%$ & $10 \%$ \\
4 "Poor" & $50 \%$ & $17 \%$ & $46 \%$ & $52 \%$ & $34 \%$ & $16 \%$ \\
\hline
\end{tabular}

Note: No probabilities are predicted for MNA because none of the five projects in the sample had less than satisfactory IP ratings.

Bank-wide, the probability of a less than satisfactory outcome (i.e. "Unsatisfactory" or "Highly Unsatisfactory") given a "poor" quality economic analysis rating at the design stage is four times higher than that for a project with "good" quality economic analysis (16 percent versus 4 percent, see Table 5). This trend seems to be consistent in all regions where the probability of unsatisfactory outcome for a project with "poor" economic analysis is three to four times higher than that for a project with "good" economic analysis at entry. No probabilities are predicted for MNA because none of the five projects in this case had less than satisfactory IP ratings. In the Africa and the South Asia regions, not only is the predicted probability of unsatisfactory outcome

\footnotetext{
${ }^{37}$ P. Belli and L. Pritchett, "Does Good Economic Analysis Lead to Better Projects?" HCO Dissemination
} 
three times higher for a project with "poor" analysis than that for a project with "good" analysis, but one out of every two projects with "poor" quality analysis is predicted to have an unsatisfactory outcome. The Bank-wide average is much lower than the regional averages. A possible reason for this may be that predicted probabilities of unsatisfactory outcomes for MNA were 0 percent, thus lowering the Bank-wide average.

While these results reaffirm the conclusions of the 1995 study by Belli and Pritchett, they are not comparable. Belli and Pritchett estimated the probabilities using a sample of 184 World Bank projects without any variance in age-all 184 projects were 3 years into implementation. A second logistic regression was estimated controlling for project age and region. In this regression (Annex 4 Logit 2), the economic analysis rating at project design stage is no longer a statistically significant indicator of project outcome. Age is now the statistically significant indicator of project outcome. One possible reason for this may be that by and large, project teams are able to adjust project performance over time and therefore lead to improved outcomes. Predicted probabilities of obtaining less than satisfactory outcomes are derived from the regression coefficients and indicated in Table 6.

Table 6: Probability of Obtaining an "Unsatisfactory" or "Highly Unsatisfactory" Rating as a Function of the Quality of the Project Economic Analysis for projects 3 years into implementation

(percent)

\begin{tabular}{ccccccc}
\hline Economic Analysis Rating & Africa & EAP & SAR & ECA & LAC & Bank \\
\hline 1 "Good" & & & & & & \\
2 "Acceptable" & $48 \%$ & $6 \%$ & $36 \%$ & $38 \%$ & $\mathbf{8 \%}$ & $7 \%$ \\
3 "Marginal" & $59 \%$ & $9 \%$ & $47 \%$ & $49 \%$ & $13 \%$ & $10 \%$ \\
4 "Poor" & $69 \%$ & $19 \%$ & $69 \%$ & $70 \%$ & $50 \%$ & $21 \%$ \\
\hline
\end{tabular}

Note: No probabilities are predicted for MNA because none of the five projects in the sample had less than satisfactory IP ratings.

Bank-wide, education projects with "poor" economic analysis are three times more likely to have unsatisfactory outcomes than those with "good" quality analysis. This relation appears to

Notes No. 53. Washington, D.C.: World Bank, 1995. This analysis did not include any education projects. 
be consistent in all regions of the World Bank. In all regions (except for MNA and LAC), a project with "poor" quality analysis is two to three times more likely to have unsatisfactory outcomes than one with "good" quality analysis. This relationship is especially pronounced in the Latin America Region, where the predicted probability of unsatisfactory outcomes increases six fold with a "poor" quality project.

The predicted probabilities of the relationships between project IP and economic analysis outcome seem to reaffirm the study hypothesis. Economic analysis rating is a statistically significant indicator of project outcome with or without controlling for project region (see Annex 4, Logits 1 and 3). But controlling for project age renders the economic analysis variable insignificant (see Annex 4, Logits 1 and 2). One possible reason, as mentioned earlier, may be that by and large, project teams are able to adjust project performance over time and therefore lead to improved outcomes.

\section{Summary and Conclusions}

The statistical analyses in this study showed that there is a strong relation between $\mathrm{CB} / \mathrm{CE}$ analysis (dimension 4) and project outcomes. The breakdowns of project economic analysis and outcome ratings, tests of cross-tabulations and multivariate logistic regressions, all supported the relationship between $\mathrm{CB} / \mathrm{CE}$ analysis and project outcomes. This is indicative of the importance of good quality $\mathrm{CB} / \mathrm{CE}$ analysis at project design stage. Project economic analysis is a tool to weed out poor potential investments and to select potentially worthwhile investments. Project economic analysis could be used to select among alternative projects or to re-design project components so that they will be higher yielding and more likely to have satisfactory outcomes. It is the $\mathrm{CB} / \mathrm{CE}$ analysis that provides clear guidelines in making such a decision. 
Chi-square tests of statistical significance indicated that the quality of the $\mathrm{CB} / \mathrm{CE}$ analysis was significantly related (at the 5 percent level) to the IP rating. Additionally, the fiscal impact analysis (dimension 3), beneficiary assessment and poverty analysis (dimension 7) and overall rating (dimension 10) are significantly related (at the 10 percent level) to IP rating (Annex 3 ).

Statistical analyses also indicated that poorly prepared projects are more likely to perform worse. Bank-wide, projects rated "poor" in terms of the quality of $\mathrm{CB} / \mathrm{CE}$ analysis were four times more likely to have less than satisfactory implementation progress than those rated "good." This result is also consistent across regions (Tables 5 and 6 ).

No statistically significant relation was found between the quality of economic analysis rating (dimension 10) and the $\mathrm{DO}$ rating. Nor was there a relation between the quality of $\mathrm{CB} / \mathrm{CE}$ analysis and expected DO ratings. In fact, cross-tabulation between rating on all other dimensions of economic analysis (except beneficiary assessment and poverty analysis) and the DO rating were negative in value. One possible explanation for this could be that because task managers tend to be optimistic about the achievement of DO through the implementation period of a project, they give it a satisfactory rating despite implementation issues. This optimism may prove to be unfounded at the end of the implementation period.

Analyses in this study support the importance of good quality $\mathrm{CB} / \mathrm{CE}$ analysis as a tool to choose among alternative project designs as well as among alternative projects. ECON evaluations suggest that $\mathrm{CB} / \mathrm{CE}$ analysis is being used more frequently since about FY 96 than in prior years in education projects. It might be worthwhile to document the kinds of costs and sources of benefits in education $\mathrm{CB} / \mathrm{CE}$ analyses to guide task managers about possible kinds of analyses used to justify education projects.

Economic analysis tools broadly considered would be inadequately employed if they are used solely to select among rather similar alternative project designs. These tools are better 
employed to select among quite different projects that accomplish the same objectives or among widely differing design alternatives.

In addition to the pre-requisites for good quality economic analysis-demand analysis, counterfactual private sector supply, fiscal impact of project, fungibility of lending-it is observed that all of the good practice education projects (see Annex 5) rely on strong sector work prior to project design. Research indicates that sector work has a significant positive impact on various measures of the quality of World Bank projects. Deininger, Squire and Basu conclude "an increase of one staff-week in the amount of time devoted to ESW [sector work] before project initiation is associated with an increases in the economic rate of return for an individual project of between 0.02 and 0.04 percentage point... $\$ 1$ of ESW [sector work] yields $\$ 4$ to $\$ 8$ in development impact." ${ }^{38}$ Further research might be undertaken to document the correlation between sector work prior to project design and project outcome rating for education investments.

\footnotetext{
${ }^{38}$ Klaus Deininger, Lyn Squire, and Swati Basu. "Does Economic Analysis Improve the Quality of Foreign Assistance?" The World Bank Economic Review, 12: 3, 385-418, 1998.
} 


\section{Annex 1: Ten Dimensions of Economic Analysis}

(http://www.worldbank.org/education/economicsed/project/projwork/ten/ten_dimentions.htm)

"The Bank evaluates investment projects to ensure that they promote the development goals of the borrower country. For every investment project, Bank staff conduct economic analysis to determine whether the project creates more net benefits to the economy than other mutually exclusive options for the use of the resources in question" (from OP 10.04).

The following is extracted from the Handbook on Economic Analysis of Investment Operations, OPR and LLC, The World Bank, 1996.

1. Project coherently set in the CAS and ESW

The purpose of this category of analysis is to ensure that the project is consistent with the country Assistance Strategy, is anchored in country policy/sector analysis and reflects lessons learned from the Bank's experience.

Are there clear objectives which can be linked to the underlying macro-economic and sectorspecific context? Is the education sector indicated as a priority area in the investment pipeline? Does the macro-economic framework have an impact on education or visa versa? Are there underlying macro- or micro-economic distortions that need to be corrected? Are there flaws in the CAS/CEM analysis relative to the education sector? Has education sector work been done? Is it linked to the CAS/CEM and does it establish clear education sector priorities which reflect dialogue with the Government? What is the policy framework that guides resource allocation within the sector? Is there overstaffing? How are non-teaching inputs in primary education being protected? How demand responsive is post-primary education? How are public resources being allocated to make the system more demand responsive? Is there competition among schools? Are there any restrictions on entry of the private sector? Are there impediments to charging tuition? Is there equitable access to education by girls? Can or should the project be used to induce policy changes?

\section{Evidence of Quantitative Analysis of Alternative Project Design}

The purpose of this category of analysis is to ensure that mutually exclusive, alternative project designs are considered.

Is there evidence of constraints to market-based solutions which should be validated before turning to the public sector provision and/or financing (past market failure or externalities which cannot be corrected through regulations, incentives, information or other techniques)? Which activities are better done by the private sector and which by the public sector? Has a full range of alternative approaches been considered for improving education outcomes, including investments outside the education sector? Have alternative design options relating to process, time and size been fully explored such as "by whom," "when," "how well" and "big" versus "small"? Has least-cost analysis been made of the major alternative strategies and design options? Has a thorough assessment been made of demand as well as the behavior of the winners, losers and those who will pay?

\section{Fiscal Impact and Cost Recovery}

The fiscal impact of the project should always be analyzed given the importance of fiscal policy for overall macroeconomic stability. 
Have the fiscal and macro-economic implications-impact on the total tax burden, public debt, inflation, economic growth and labor markets-been fully explored through economic modeling and financial projections of revenues and recurrent expenditures? Has an analysis been made of both fiscal and private affordability? Are proposed direct charges and cost recovery mechanisms consistent with the public/private justification, affordability discussion and poverty implications?

\section{Completeness and Internal Coherence of Cost-Benefit Analysis or Other Selection Criteria}

Whenever reasonable estimates can be made, cost benefits should be quantified so that the analyst can decide whether the project is worth undertaking.

Have alternative ways of achieving the project objectives been evaluated? For example, should budget resources in the sector be reallocated? Are capacity increases really necessary? If so, should they focus on improving quality or expanding coverage? Is there evidence of the value of the services to be provided by the project? An effort should be made to quantify those benefits (for example, by using projected wage differentials or increased productivity in labor markets. Additional evidence would be indicators of excess demand for the type of schooling being expanded by the project. Other non-market benefits - such as impact on fertility, ability to cope with diseases - should be discussed. While estimation of NPV/ERR is not required for education projects, analysis of private and social returns is encouraged for best practice. Does the evaluation include adequate cost effectiveness analysis? This will normally involve using quantitative indicators of inputs and results (e.g., number of teachers trained, training days per staff worker, etc.). Are project activities the least cost way of achieving these results? If cost-benefit or costeffectiveness analysis is not possible, and if no cost data are available, then it must be explained why this project is chosen and that cost data will be generated during implementation. In the absence of cost and benefit information, a qualitative account of the expected development impact must be included.

\section{Sensitivity/Risk Analysis}

The main elements which need to be assessed include the impact that changes in different underlying parameters will have on the anticipated outcome of the operation and its vulnerability to potential risk factors.

What is the likely impact of varying some of the underlying parameters such as inputs, demand and costs on the outcome of the education sector operation? Switching values can also be used. A switching value is the value an element of a project would have to reach as a result of a change in an unfavorable direction before the project no longer meets the minimum level of acceptability as indicated by one of the measures of project worth.

\section{Institutional Capacity and Risk Analysis}

Assessment of the institutional capacity includes political, legislative and regulatory processes as well as management and administrative capacity.

Has an assessment been carried out of the full institutional capacity in the education sector? Is there an ability to influence demand? Which are the main risk factors (e.g., political instability, institutional resistance and changes in ownership)? 


\section{Poverty and Gender Analysis}

The economic analysis examines the project's consistency with the Bank's poverty reduction strategy.

Has there been a full analysis of alternatives of policy options and interventions which will have the greatest positive impact on the poor? Is targeting? Has there been a full analysis of the tradeoffs between access, cost and quality? While poverty alleviation is of vital concern to Bank operations overall, it is particularly so for basic education. Mechanisms to protect the poor must be discussed. The overall impact on poverty of interventions should be explained.

\section{Environmental Analysis and Linkage to Economic Analysis}

The effects of the project on the environment, both negative and positive, should be taken into account and if possible, quantified and monetary value.

This is usually not an issue in education projects unless new infrastructure is built. If an environmental assessment is required, then it should reflected in the economic analysis. Environmental externalities should be identified, and to the extent possible their economic implications assessed.

\section{Economic Performance Criteria}

The project indicators should be focused on the developmental objectives of the proposed operation and be sensitive to interventions which will be carried out. List the key economic performance indicators which will be used to track progress of the proposed operation? The economic performance indicators for monitoring and feedback during implementation should be identified. This includes a listing of key economic performance indicators (input, intermediate, output and outcome) which will be used to track progress of the proposed intervention. Project monitoring and economic performance indicators must be linked. In addition, assessment of outcomes without project intervention should be included; in other words, there should be a control group. The analysis should also tell us whether an education assessment system is in place, and whether it measures labor market outcomes as well as learning.

\section{Overall Ranking for Project Analysis}

Are the overall conclusions from the economic analysis consistent with the broad education sector policy framework for the country in question? This calls for qualitative assessment of the nine previous criteria. It allows one to determine whether the operation is on balance a coherent, transparent and sound assessment of expected economic performance. In addition, the economic analysis should be consistent with the broad sectoral policy framework for the country in question. 
Annex 2: Breakdowns of selected project economic analysis and outcome ratings by region of the World Bank and project age

1. Breakdowns by Region:

a. Proportion of Projects by Region with "Unsatisfactory" and "Highly Unsatisfactory" DO Ratings by Overall Economic Analysis Rating (Dimension 10)

\begin{tabular}{|l|c|c|c|c|c|c|c|}
\hline & \multicolumn{7}{|c|}{ Region } \\
\hline Overall Rating (dimension 10) & AFR & EAP & ECA & LAC & MNA & SAR & Total \\
\hline Good (1) & $29 \%$ & $0 \%$ & $25 \%$ & $0 \%$ & $0 \%$ & $20 \%$ & $12 \%$ \\
\hline Acceptable-Poor (2-4) & $27 \%$ & $0 \%$ & $0 \%$ & $5 \%$ & $0 \%$ & $33 \%$ & $11 \%$ \\
\hline Total & $27 \%$ & $0 \%$ & $10 \%$ & $0 \%$ & $0 \%$ & $29 \%$ & $11 \%$ \\
\hline
\end{tabular}

b. Proportion of Projects by Region with "Unsatisfactory" and "Highly Unsatisfactory" IP Ratings by Overall Economic Analysis Rating (Dimension 10)

\begin{tabular}{|l|c|c|c|c|c|c|c|}
\hline & \multicolumn{7}{|c|}{ Thegion } \\
\hline Overall Rating (dimension 10) & AFR & EAP & ECA & LAC & MNA & SAR & Total \\
\hline Good (1) & $14 \%$ & $0 \%$ & $25 \%$ & $0 \%$ & $0 \%$ & $20 \%$ & $9 \%$ \\
\hline Acceptable-Poor (2-4) & $40 \%$ & $8 \%$ & $33 \%$ & $18 \%$ & $0 \%$ & $44 \%$ & $24 \%$ \\
\hline Total & $32 \%$ & $5 \%$ & $30 \%$ & $13 \%$ & $0 \%$ & $36 \%$ & $19 \%$ \\
\hline
\end{tabular}

c. Proportion of Projects by Region with "Unsatisfactory" and "Highly Unsatisfactory" DO Ratings by Cost-Benefit/Cost-Effectiveness Analysis Rating (Dimension 4)

\begin{tabular}{|c|c|c|c|c|c|c|c|}
\hline & \multicolumn{7}{|c|}{ 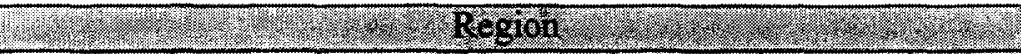 } \\
\hline $\begin{array}{l}\text { Economic Aralysis Rating } \\
\text { (dimension } 4 \text { ) }\end{array}$ & AFR & EAP & $\overline{\mathrm{ECA}}$ & LAC & $\overline{\mathrm{MNA}}$ & SAR & Total \\
\hline Good (1) & $17 \%$ & $0 \%$ & $25 \%$ & $0 \%$ & $0 \%$ & & $6 \%$ \\
\hline Acceptable-Poor (2-4) & $30 \%$ & $0 \%$ & $0 \%$ & $8 \%$ & $0 \%$ & $30 \%$ & $15 \%$ \\
\hline Total & $27 \%$ & $0 \%$ & $10 \%$ & $3 \%$ & $0 \%$ & $29 \%$ & $12 \%$ \\
\hline
\end{tabular}

d. Proportion of Projects by Region with "Unsatisfactory" and "Highly Unsatisfactory" IP Ratings by Cost-Benefit/Cost-Effectiveness Analysis Rating (Dimension 4)

\begin{tabular}{|l|c|c|c|c|c|c|c|}
\hline & \multicolumn{7}{|c|}{ Region } \\
\hline $\begin{array}{l}\text { Economic Analysis Rating } \\
\text { (dimension 4) }\end{array}$ & AFR & EAP & ECA & LAC & MNA & SAR & Total \\
\hline Good (1) & $17 \%$ & $0 \%$ & $25 \%$ & $0 \%$ & $0 \%$ & & $6 \%$ \\
\hline Acceptable-Poor (2-4) & $30 \%$ & $14 \%$ & $33 \%$ & $31 \%$ & $0 \%$ & $30 \%$ & $27 \%$ \\
\hline Total & $32 \%$ & $5 \%$ & $30 \%$ & $13 \%$ & $0 \%$ & $36 \%$ & $19 \%$ \\
\hline
\end{tabular}


1. Breakdowns by Project Cohort (Age):

a. Proportion of Projects by Project Age with "Unsatisfactory" and "Highly Unsatisfactory" DO Ratings by Overall Economic Analysis Rating (Dimension 10)

\begin{tabular}{|c|c|c|c|c|c|c|}
\hline & \multicolumn{6}{|c|}{ 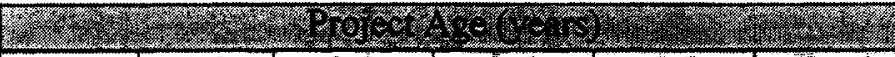 } \\
\hline Ceralmating (dimenson 10$)$ & $0-1$ & $1-2$ & $2-3$ & $3-5$ & $5-7$ & Total \\
\hline Good (1) & $0 \%$ & $11 \%$ & $11 \%$ & & $25 \%$ & $12 \%$ \\
\hline Acceptable-Poor (2-4) & $10 \%$ & $19 \%$ & $17 \%$ & $0 \%$ & $6 \%$ & $11 \%$ \\
\hline Total & $6 \%$ & $16 \%$ & $15 \%$ & $0 \%$ & $13 \%$ & $12 \%$ \\
\hline
\end{tabular}

b. Proportion of Projects by Project Age with "Unsatisfactory" and "Highly Unsatisfactory" IP Ratings by Overall Economic Analysis Rating (Dimension 10)

\begin{tabular}{|l|c|c|c|c|c|c|}
\hline & & & & & & \\
\hline
\end{tabular}

c. Proportion of Projects by Project Age with "Unsatisfactory" and "Highly Unsatisfactory" DO Ratings by Cost-Benefit/Cost-Effectiveness Analysis Rating (Dimension 4)

\begin{tabular}{|l|c|c|c|c|c|c|}
\hline & \multicolumn{3}{|c|}{ Total } \\
\hline F & $0-1$ & $1-2$ & $2-3$ & $3-5$ & $5-7$ & Tot \\
\hline Good (1) & & & & & & $6 \%$ \\
\hline Acceptable-Poor (2-4) & $17 \%$ & $19 \%$ & $16 \%$ & $0 \%$ & & $15 \%$ \\
\hline Total & $6 \%$ & $16 \%$ & $15 \%$ & $0 \%$ & $13 \%$ & $12 \%$ \\
\hline
\end{tabular}

d. Proportion of Projects by Project Age with "Unsatisfactory" and "Highly Unsatisfactory" IP Ratings by Cost-Benefit/Cost-Effectiveness Analysis Rating (Dimension 4)

\begin{tabular}{|c|c|c|c|c|c|c|}
\hline & \multicolumn{3}{|c|}{ 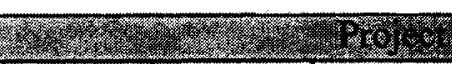 } & & & \\
\hline (a) & $0-1$ & $1-2$ & $2-3$ & $3-5$ & $5-7$ & Total \\
\hline Good (1) & $0 \%$ & $11 \%$ & $13 \%$ & $0 \%$ & & $6 \%$ \\
\hline Acceptable-Poor (2-4) & $17 \%$ & $25 \%$ & $32 \%$ & $29 \%$ & & $27 \%$ \\
\hline Total & $6 \%$ & $20 \%$ & $26 \%$ & $\overline{20 \%}$ & $21 \%$ & $19 \%$ \\
\hline
\end{tabular}




\section{Annex 3: Cross-tabulation Test Results}

Cross-tabulations - Project Outcomes by Economic Analysis in SAR/PAD Chi-Square significance test results

\begin{tabular}{|c|c|c|}
\hline \multirow[b]{2}{*}{ Dimensions of Economic Analysis $^{c}$} & \multicolumn{2}{|c|}{ Project Outcomes $^{\sigma}$} \\
\hline & $\begin{array}{c}\text { Development } \\
\text { Objectives }\end{array}$ & $\begin{array}{c}\text { Implementation } \\
\text { Progress }\end{array}$ \\
\hline 1. ESW and CAS & NV & 0.33 \\
\hline 2. Analysis of Alternatives & NV & 0.18 \\
\hline 3. Fiscal Impact Analysis/Cost recovery & NV & $0.07 \#$ \\
\hline 4. Quality and Clarity of $\mathrm{CB} / \mathrm{CE}$ analysis & 0.27 & 0.02 \# \\
\hline 6. Institutional Risk Analysis & NV & 0.95 \\
\hline 7. Beneficiary Assessment \& Poverty Analysis & 0.29 & 0.08 \# \\
\hline 10. Overall Rating & NV & $0.06 \#$ \\
\hline
\end{tabular}

Notes:

a All variables dichotomous and coded as follows:

Economic Analysis

$$
\begin{aligned}
& 0=\text { good } \\
& 1=\text { acceptable or poor }
\end{aligned}
$$

Project Outcomes

$0=$ HS (highly satisfactory) or S (satisfactory)

$1=\mathrm{U}$ (unsatisfactory) or HU (highly unsatisfactory)

${ }^{\mathrm{b}}$ Chi-square significance test results

\#\# = significant at 0.05 probability level

$\#$ = significant at 0.10 probability level

$\mathrm{NV}=$ negative value although positive value was predicted

${ }^{c}$ No ECON ratings for three of the ten dimensions of economic analysis:

5. Sensitivity Analysis

8. Environmental Analysis

9. Economic Performance Criteria 


\section{Annex 4: Multivariate Logit Regressions}

The analysis is based on a logit model of the form:

$$
\log [p /(1-p)]=a+b(D 4)+c(A F R)+d(E A P)+f(M N A)+g(S A R)+h(E C A)+e
$$

where D4 stands for the quality of the project's economic analysis rating, AFR indicates whether or not the project is in the Africa region, EAP indicates whether or not the project is in the East Asia and Pacific region, MNA indicates whether or not the project is in the Middle East and North Africa region, SAR indicates whether or not the project is in the South Asia region, ECA indicates whether or not the project is in the East and Central Europe region, and e stands for an error term.

Based on a sample of 79 observations, the coefficients of the regression were estimated as indicated in Logit 1 below.

\begin{tabular}{lccc} 
Variable & Logit 1 & Logit 2 & Logit 3 \\
\hline D4 & $0.548^{*}$ & 0.458 & $1.68^{*}$ \\
& $(0.300)$ & $(0.345)$ & $(0.799)$ \\
AFR & 0.694 & $1.857^{*}$ & \\
& $(0.837)$ & $(1.128)$ & \\
EAP & -0.925 & -0.403 & \\
MNA & $(1.199)$ & $(1.304)$ & \\
& -6.231 & -7.039 & \\
SAR & $(24.328)$ & $(38.626)$ & \\
& 0.514 & 1.830 & \\
ECA & $(0.903)$ & $(1.189)$ & \\
& 0.735 & 1.893 & \\
Age & $(0.920)$ & $(1.192)$ & \\
& & $1.005^{*}$ & $(0.464)$ \\
Constant & $-5.858^{*}$ & $-2.67^{*}$ \\
Number & $-2.865^{*}$ & $(2.007)$ & $(0.731)$ \\
\hline
\end{tabular}

1. Asterisk $\left(^{*}\right)$ indicates that the coefficient is statistically significant at the 10 percent level.

2. Standard errors indicated in ().

3. The variable AGE represents the project age since effectiveness up to June 30, 1999. 


\section{Annex 5: Good Practice Project Analyses}

Four project analyses have been chosen to illustrate "good practice" with emphasis on economic analysis but also showing very strong overall project design. All were given a "1" rating in various ECON reports evaluating the quality of World Bank project analyses. All can serve as examples for others preparing education project analyses.

Viet Nam Higher Education Project. (Report No. 17235-VN)

The economic analysis of the Viet Nam Higher Education Project rests on two benefit streams: (1) cost savings at the institutional level arising from improvements in university administration and economies of scale reflecting the elimination of undersized universities, and (2) an increase in the incremental earnings of university graduates as a result of more efficient learning and introduction of modernized curricula more relevant to the emerging market economy. However the report notes, "the rate of return calculated in this analysis is driven primarily by the second of the two benefits." The benefits of the two streams are compared with the costs of the project and an internal rate of return of return of 18 percent is derived. The most probable outcome assumptions are then subjected to seven sensitivity analyses. These then yield internal rates of return ranging from a high of 38 percent (assuming a higher wage differential for graduates from modernized curricula) to a low of 15 percent (including several costs included in the project but which were deemed to contribute neither to cost savings nor to modernizing curricula). The authors of the report also note at least five kinds of non-quantifiable benefits arising from the project and note these benefits are in addition to the quantifiable benefits used in the benefit-cost analysis.

This project analysis also includes a strong financial analysis. Using government higher education past expenditures and proposed budgets, the analysis demonstrates that the "incremental recurrent costs resulting from the project are well within the capacity of the government's projected higher education budget" and that the project activities could be sustained from regular government budget sources after loan disbursements are completed. Both the economic analysis and the financial analysis benefited from the use of the COSTAB computer program, although none of the COSTAB tables are included in the Project Appraisal Document.

It should be noted that a contributor to the high quality of the project analysis was the very extensive sector work which preceded project preparation. These included the Viet Nam Education Sector Financing Sector Study and the 1996 Higher Education Graduate Tracer Study, as well as a number of specialized background papers.

East Java and East Nusa Tenggara Junior Secondary Education Project (Report 15501IND)

The exemplary economic analysis in the East Java and East Nusa Tenggara Junior Secondary Education Project is divided into four parts. These are "(i) demand analysis and rationale for public investment in junior secondary; (ii) fiscal analysis; (iii) analysis of alternatives; and (iv) cost-benefit analysis. 
"The economic analysis first aims to understand the determinants of demand for junior secondary education in Indonesia particularly since there have been variations in the past decade and there are significant disparities among socio-economic groups. . . This section establishes that the main determinants of demand are household incomes, costs of schooling and distance to school; the latter two are variables that Government can effect through this project. The rationale for additional public investment in junior secondary is investigated subsequently ... and it is argued that on both efficiency and equity grounds, there are justifications for additional public intervention in expanding junior secondary.

"The cost implications of the Government's expansion program . . . are then considered. A key element is the future role of the private sector in the provision of junior secondary education. The conclusions reached are that a sizable budgetary effort will be required, but that the policy is attainable if the economy continues to grow at its historical rate, additional funds are made available to junior secondary including external borrowing and the private sector retains its current large share.

"The next question that arises is how best to provide junior secondary education. The Government has at its reach both demand and supply policy instruments and within the latter several alternative modes of junior secondary exist. . .

"Finally, the costs and benefits of the specific project design are laid out and an economic rate of return is calculated. The financial impact of the project on the provincial budgets and prospects of sustainability is analyzed in [the] section" devoted to cost implications. The benefit stream in the benefit-cost analysis rests upon increasing access to junior secondary education (thus giving rise to incremental wages of the graduates) and upon enhancing the quality of junior secondary schools assisted by the project and the assumption that a " 15 percent additional wage premium can be earned by higher quality graduates." The most probable outcome IRR of 18 percent for the project as a whole is then subjected to five separate sensitivity analyses. The sensitivity analysis concludes, "in all, the main variables to which the system appears to be most sensitive are those affecting quality. This is not surprising given the large numbers of beneficiaries which are impacted by this investment."

This economic analysis is distinguished not only by its completeness, but also by detailed exposition including both tables and graphs, by its emphasis on the rationale for the project, and by the explicit exploration of alternatives. Good use is made of cosTAB tables.

This project is one of several projects being supported by the World Bank to extend junior secondary education. The analysis benefits not only from World Bank experience in similar projects, but also from the long history of World Bank lending for education in Indonesia and from extensive sector work. Once again the importance of thorough knowledge of the sector within the borrowing country and of good sector work is highlighted. 
The Ethiopian Education Sector Development Program is a wide-ranging project, but almost 60 percent of the total expenditure is focused on primary school expansion to help Ethiopia reach its goal of universal primary education by 2015 .

The economic analysis of the program uses data from available survey sources to estimate both private rates of return at the primary, secondary and tertiary level and also social (economic) rates of return by level. The analysis does not attempt an estimate of the return to the investment in the project per se; rather it assumes that the broad estimates at the sector level adequately reflect the return to the investment in the project. An interesting outcome is that private returns to education at private, secondary, and tertiary education level are all on the order of 24 to 27 percent. However, social rates of return are highest at the primary level where the IRR is 15 percent and lowest at the tertiary level which nonetheless is on the order of 12 percent.

This economic analysis is particularly interesting in its analysis of the choice of technology for school construction. Using a cross-over discount rate approach, the analysis shows that at an opportunity cost of capital below 23 percent permanent building alternatives (primarily hollow concrete block) are preferable to traditional mud and thatch construction.

The economic analysis examines in some detail the fiscal impact of the government's Education Sector Development Program. The analysis concludes that the Education Sector Development Program will be feasible, although there will be a need for continued external donor support and also that it may be necessary to slow an ambitious road construction plan to assure sufficient capital for school construction.

The project design, and, hence, the analysis is greatly informed by World Bank sector work, particularly the Ethiopian Social Sector Strategy Note and a Public Expenditure Review. Since the project is intended to support the Education Sector Development Program, the analysis draws heavily on that document, especially its analysis of alternative scenarios -- in effect, sensitivity analyses.

\section{El Salvador Education Reform Project (Report No. 17415-ES)}

The economic analysis for the El Salvador Education Reform Project takes as its benefit incremental earnings by students completing nine grades of primary education. The incremental earnings are derived from household survey data. The costs are the full project cost and imputed opportunity cost for each of the components evaluated. (A pilot project is not subjected to analysis.) An internal rate of return is computed both for each of the three major components and for the project as a whole. Each estimate is subjected to a sensitivity analysis, and switching values are computed for each. Estimating the rate of return to each component assures that there is not a component which falls below the cut-off rate but which might be hidden if only a rate of return for the whole project were computed.

A separate fiscal analysis annex is included in the PAD. It briefly outlines the history of expenditure levels on primary education in El Salvador, noting that the expenditure level 
as a proportion of GDP is low in comparison with other Central American countries, as is the absolute amount of expenditure for each pupil. The analysis sets out a target for increasing the proportion of GDP devoted to primary education related to projections of the growth in GDP and details projected changes in GDP and the expenditure on both the education sector and on the project over a 14 year period.

The El Salvador analyses benefited from considerable sector work including a World Bank country study and a study of returns to secondary education which included an estimate of the sector returns to primary education. 


\section{Policy Research Working Paper Series}

Title

WPS2542 Checks and Balances, Private
Information, and the Credibility of
Monetary Commitments

WPS2543 When Do Special interests Run Rampant? Disentangling the Role in Banking Crises of Elections, Incomplete information, and Checks and Balances

WPS2544 The Uniqueness of Short-Term Collateralization

WPS2545 Financing the Future: Infrastructure Needs in Latin America, 2000-05

WPS2546 Gender Dimensions of Pension Reform in the Former Soviet Union

WPS2547 The Design of Incentives for Health Care Providers in Developing Countries: Contracts, Competition, and Cost Control

WPS2548 International Provision of Trade Services, Trade, and Fragmentation

WPS2549 Measuring Poverty Dynamics and Inequality in Transition Economies: Disentangling Real Events from Noisy Data

WPS2550 Measuring Equity in Health Care Financing: Reflections on (and Alternatives to) the World Health Organization's Fairness of Financing Index

WPS2551 Infrastructure Coverage and the Poor: A Global Perspective
WPS2552 Inventories in Developing Countries: Levels and Determinants-a Red Flag Joseph Kogan For Competitiveness and Growth

WPS2553 The Value of Relationship Banking during Financial Crises: Evidence from the Republic of Korea
Author

Philip Keefer

David Stasavage

Philip Keefer

Leora Klapper

Marianne Fay

Paulette Castel

Louise Fox

Jeffrey S. Hammer

William G. Jack

Alan V. Deardorff

Erzo F. P. Luttmer

Adam Wagstaff

Kristin Komives

Dale Whittington Xun Wu

J. Luis Guasch

Giovanni Ferri Tae Soo Kang In-June Kim
Date

February 2001

February 2001

February 2001

February 2001

February 2001

February 2001

February 2001

February 2001

February 2001

February 2001

February 2001

J. Troncoso 37826

\section{Contact} for paper

P. Sintim-Aboagye 37644

P. Sintim-Aboagye 37644

A. Yaptenco 31823

A. François 37841

J. Smith 87215

H. Sladovich 37698

L. Tabada 36896

C. Wodon 32542

A. Maranon 38009

S. Minovi 30012

February 2001

A. Yaptenco 31823 


\section{Policy Research Working Paper Series}

\begin{tabular}{|c|c|c|c|c|}
\hline & Title & Author & Date & $\begin{array}{l}\text { Contact } \\
\text { for paper }\end{array}$ \\
\hline WPS2554 & $\begin{array}{l}\text { Administrative Costs and the } \\
\text { Organization of Individual } \\
\text { Retirement Account Systems: } \\
\text { A Comparative Perspective }\end{array}$ & $\begin{array}{l}\text { Estelle James } \\
\text { James Smalhout } \\
\text { Dimitri Vittas }\end{array}$ & February 2001 & $\begin{array}{l}\text { A. Yaptenco } \\
31823\end{array}$ \\
\hline WPS2555 & $\begin{array}{l}\text { Implicit Pension Debt, Transition } \\
\text { Cost, Options, and Impact of } \\
\text { China's Pension Reform: } \\
\text { A Computable General Equilibrium } \\
\text { Analysis }\end{array}$ & $\begin{array}{l}\text { Yan Wang } \\
\text { Dianqing Xu } \\
\text { Zhi Wang } \\
\text { Fan Zhai }\end{array}$ & February 2001 & $\begin{array}{l}\text { A. Datoloum } \\
36334\end{array}$ \\
\hline WPS2556 & $\begin{array}{l}\text { Househoid Strategies for Coping with } \\
\text { Poverty and Social Exclusion in } \\
\text { Post-Crisis Russia }\end{array}$ & $\begin{array}{l}\text { Michael M. Lokshin } \\
\text { Ruslan Yemtsov }\end{array}$ & February 2001 & $\begin{array}{l}\text { P. Sader } \\
33902\end{array}$ \\
\hline WPS2557 & $\begin{array}{l}\text { Decentralization and Accountability: } \\
\text { Are Voters More Vigilant in Local than } \\
\text { in National Elections? }\end{array}$ & Stuti Khemani & February 2001 & $\begin{array}{l}\text { H. Sladovich } \\
37698\end{array}$ \\
\hline WPS2558 & $\begin{array}{l}\text { Growth, Inequality, and Poverty: } \\
\text { Looking beyond Averages }\end{array}$ & Martin Ravallion & February 2001 & $\begin{array}{l}\text { P. Sader } \\
33902\end{array}$ \\
\hline WPS2559 & $\begin{array}{l}\text { Deposit Insurance as Private Club: } \\
\text { Is Germany a Model? }\end{array}$ & Thorsten Beck & February 2001 & $\begin{array}{l}\text { P. Sintim-Aboagye } \\
38526\end{array}$ \\
\hline WPS2560 & $\begin{array}{l}\text { Catastrophe Risk Management: } \\
\text { Using Alternative Risk Financing } \\
\text { and Insurance Pooling Mechanisms }\end{array}$ & John D. Pollner & February 2001 & $\begin{array}{l}\text { J. Pollner } \\
30079\end{array}$ \\
\hline WPS2561 & $\begin{array}{l}\text { Democracy and Income Inequality: } \\
\text { An Empirical Analysis }\end{array}$ & $\begin{array}{l}\text { Mark Gradstein } \\
\text { Branko Milanovic } \\
\text { Yvonne Ying }\end{array}$ & March 2001 & $\begin{array}{l}\text { P. Sader } \\
33902\end{array}$ \\
\hline WPS2562 & $\begin{array}{l}\text { Decomposing World Income } \\
\text { Distribution: Does the World Have a } \\
\text { Middle Class? }\end{array}$ & $\begin{array}{l}\text { Branko Milanovic } \\
\text { Shlomo Yitzhaki }\end{array}$ & March 2001 & $\begin{array}{l}\text { P. Sader } \\
33902\end{array}$ \\
\hline WPS2563 & $\begin{array}{l}\text { A Race to the Top? A Case Study of } \\
\text { Food Safety Standards and African } \\
\text { Exports }\end{array}$ & $\begin{array}{l}\text { Tsunehiro Otsuki } \\
\text { John S. Wilson } \\
\text { Mirvat Sewadeh }\end{array}$ & March 2001 & $\begin{array}{l}\text { L. Tabada } \\
36896\end{array}$ \\
\hline
\end{tabular}

